\title{
ABOVEGROUND AND BELOWGROUND BIOMASS AND CARBON ESTIMATES FOR CLONAL EUCALYPTUS TREES IN SOUTHEAST BRAZIL ${ }^{1}$
}

\author{
Sabina Cerruto Ribeiro² ${ }^{2}$ Carlos Pedro Boechat Soares ${ }^{3}$, Lutz Fehrmann ${ }^{4}$, Laércio Antônio Gonçalves \\ Jacovine $^{3}$ e Klaus von Gadow ${ }^{4}$
}

\begin{abstract}
Eucalyptus plantations represent a short term and cost efficient alternative for sequestrating carbon dioxide from the atmosphere. Despite the known potential of forest plantations of fast growing species to store carbon in the biomass, there are relatively few studies including precise estimates of the amount of carbon in these plantations. In this study it was determined the carbon content in the stems, branches, leaves and roots of a clonal Eucalyptus grandis plantation in the Southeast of Brazil. We developed allometric equations to estimate the total amount of carbon and total biomass, and produced an estimate of the carbon stock in the stand level. Altogether, 23 sample trees were selected for aboveground biomass assessment. The roots of 9 of the 23 sampled trees were partially excavated to assess the belowground biomass at a singletree level. Two models with $D B H, H$ and $D B H^{2} H$ were tested. The average relative share of carbon content in the stem, branch, leaf and root compartments was $44.6 \%, 43.0 \%, 46.1 \%$ and $37.8 \%$, respectively, which is smaller than the generic value commonly used (50\%). The best-fit allometric equations to estimate the total amount of carbon and total biomass had $D B H^{2} H$ as independent variable. The root-to-shoot ratio was relatively stable $(\mathrm{C} . \mathrm{V} .=27.5 \%)$ probably because the sub-sample was composed of clones. Total stand carbon stock in the Eucalyptus plantation was estimated to be $73.38 \mathrm{MgC} \mathrm{ha}^{-1}$, which is within the carbon stock range for Eucalyptus plantations.
\end{abstract}

Keywords: Carbon stock; Allometric equation; Carbon content.

\section{BIOMASSA ACIMA E ABAIXO DO SOLO E ESTIMATIVAS DE CARBONO PARA UM PLANTIO CLONAL DE EUCALIPTO NO SUDESTE DO BRASIL}

\begin{abstract}
RESUMO - Os plantios de eucalipto são uma alternativa rentável e de curto prazo para sequestrar o dióxido de carbono da atmosfera. Apesar de se conhecer o potencial de estoque de carbono na biomassa das florestas plantadas com espécies de rápido crescimento, existem relativamente poucos estudos que incluem estimativas precisas da quantidade de carbono nesses povoamentos. Em vista disso, este estudo objetivou a determinação do teor de carbono no tronco, galhos, folhas e raízes de um plantio clonal de Eucalyptus grandis no Sudeste do Brasil. Equações alométricas para estimar a quantidade total de carbono e biomassa também foram desenvolvidas e estimativas do estoque de carbono no povoamento, geradas. Inicialmente, selecionaram-se 23 árvores-amostra para quantificação da biomassa. As raízes de 9 das 23 árvores-amostra foram parcialmente escavadas para estimação da biomassa abaixo do solo, em nível de árvore individual. Dois modelos usando as variáveis independentes DAP, altura $(H)$ e DAP ${ }^{2} H$ foram testados. O teor de carbono médio do tronco, galhos, folhas e raízes foi de 44,6\%, 43,0\%, 46,1\% e 37,8\%, respectivamente, sendo menor do que o valor genérico comumente usado (50\%). As equações alométricas de melhor ajuste para estimar a quantidade
\end{abstract}

\footnotetext{
${ }^{1}$ Recebido em 20.12.2013 aceito para publicação em 09.12.2014.

${ }^{2}$ Universidade Federal do Acre, Centro de Ciências Biológicas e da Natureza, Curso de Engenharia Florestal, Rio Branco, AC - Brasil.E-mail: <sabina.ufac@gmail.com>.

${ }^{3}$ Universidade Federal de Viçosa, Centro de Ciências Agrárias, Departamento de Engenharia Florestal - Viçosa, MG - Brasil. E-mail: <csoares@ufv.br>e <jacovine@ufv.br>.

${ }^{4}$ Georg-August-Universität Göttingen, Faculdade de Ciência Florestal e Ecologia Florestal, Departamento de Inventário Florestal e Sensoriamento Remoto - Göttingen, Baixa Saxônia - Alemanha. E-mail: <lfehrma@gwdg.de>e <kgadow@gwdg.de>
}

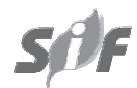

Revista Árvore, Viçosa-MG, v.39, n.2, p.353-363, 2015

http://dx.doi.org/10.1590/0100-67622015000200015 
total de carbono e biomassa apresentavam o $D A P^{2} H$ como variável independente. A razão raiz-parte aérea foi relativamente estável (C.V. $=27,5 \%)$ em razão, provavelmente, do fato de a subamostra ser composta por clones. O estoque de carbono total para o povoamento de eucalipto foi estimado em 73,38 $\mathrm{MgC} \mathrm{ha}^{-1}$, valor semelhante ao encontrado em outros povoamentos de eucalipto.

Palavras-chave: Estoque de carbono; Equação alométrica; Teor de carbono.

\section{INTRODUCTION}

Eucalyptus plantations occupy more than 20 million hectares worldwide. They are widespread, especially in tropical regions (IGLESIAS et al., 2009; LACLAU et al., 2010). In Brazil, Eucalyptus plantations cover more than 4 million hectares and are mainly used to produce pulpwood and the renewable charcoal required by mining and steel-producing industries (ABRAF, 2012).

Different fast-growing and well-adapted Eucalyptus cultivars have been developed through natural and artificial hybridization (WEI; XU, 2002). One of these is the hybrid clone E. urophylla S.T. Blake and E. grandis Hill ex Maiden, which is known as E. urograndis. This clone is widely distributed in tropical and subtropical regions, being the most favored for pulp production and for solid wood (ROCKWOOD et al., 2008). Most of the urograndis plantations are situated in the Congo basin (MATONDO et al., 2005), in Brazil (SILVÉRIO et al., 2007) and in China (ZHOU et al., 2008).

Since the earliest discussions about climate change, forests have be enconsidered important for mitigating the greenhouse effect (SCHLAMADINGER et al., 2007). Forest plantations, especially those with fast growing species such as Eucalyptus and its cultivars, represent a short term and cost efficient alternative for sequestrating the carbon which would otherwise be emitted to the atmosphere (STERN, 2007; ZHANG et al., 2012).

Within this context, Brazil assumes a privileged position as one of the few countries in the world with the appropriate climate and technological conditions for forest production (STAPE et al., 2001; GONÇALVES et al., 2008). However, to assess the Brazilian potential of carbon storage in forest plantations, it is essential to have reliable estimates of biomass.

Biomass estimation of forest trees has been subject to research for a long time (FEHRMANN; KLEINN, 2006). A common approach to estimating biomass is the use of regression analysis and the development of allometric equations (PARRESOL, 1999). Usually allometric models are adjusted using three basic sources of information: dry samples of different tree compartments, the bulk density and the volume of the wood. Based on this data one obtains the total dry mass which is usually related to the diameter at breast height (dbh) and the height of the tree by an allometric relationship (HENRY et al., 2010).

Most of the allometric equations for forest plantations were developed to estimate the aboveground biomass. However, there is still a lack of studies including precise estimates of the amount of carbon in the various forest compartments, such as the roots, leaves and branches. According to Kauffman et al. (2009), the understanding of the dynamic development of carbon sinks and sources is important in establishing strategies related to the Clean Development Mechanism (CDM) and in planning future actions related to the Reducing Emissions from Deforestation and Forest Degradation (REDD).

In this study we sought to fill some of the knowledge gaps in Eucalyptus carbon studies. Allometric equations for estimating the amount of carbon in the biomass of stems, branches and leaves of a commercial Eucalyptus plantation are developed. The amount of carbon in root biomass is also assessed through destructive procedures and estimates of carbon stock in the stand level are generated.

\section{MATERIALS AND METHODS}

\subsection{Study area}

This study was conducted in a Eucalyptus plantation owned by the company Plantar S.A. The plantation is located near the municipality of Curvelo, in the central part of Minas Gerais, Brazil. The climate in the region is subtropical, with a marked dry season from April to October. January and February are the months with the highest precipitation. The average annual rainfall is between $1100 \mathrm{~mm}$ and $1200 \mathrm{~mm}$. The hottest month has an average temperature of $26^{\circ} \mathrm{C}$ and the coldest one of $21^{\circ} \mathrm{C}$.

Revista Árvore, Viçosa-MG, v.39, n.2, p.353-363, 2015

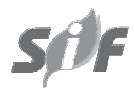


The soil type in the study area is dominated by red latosol, which is characterized by high clay content, low levels of organic matter and low fertility. The topography of the study site is flat with an elevation of approximately $600 \mathrm{~m}$.

The study was started in 2008 in a plantation compartment covering an area of 31 ha in total. The site was planted with a Eucalyptus hybrid clone of Eucalyptus urophylla S.T. Blake and Eucalyptus grandis Hill ex Maiden. At the start of the study the age of the plantation was 5.5 years. The initial plant spacing was $3 \mathrm{~m} \times 3 \mathrm{~m}$. The average tree height at that age was $26.3 \mathrm{~m}$ and the average tree diameter at breast height of the stand was $15.7 \mathrm{~cm}$.

\subsection{Data collection}

Altogether 23 sample trees were selected for aboveand belowground biomass assessment. The selection of sample trees was random and within the diameter classes observed on the Eucalyptus plantation.

The sample trees were used to develop allometric equations for estimating the aboveground amount of carbon in the biomass of stems, branches and leaves. The roots of 9 of the 23 sampled trees were partially excavated to assess the belowground biomass and carbon content of this compartment at a single-tree level (Table 1).

The dbh, total height and commercial height (the stem height up to a diameter of $3 \mathrm{~cm}$ ) was measured for each tree sampled (Table 1). The volume (inside and outside bark) of each stem section was calculated using Smalian's formula. The stem diameters with bark and the bark thicknesses were recorded at stem heights of $0.3 \mathrm{~m}, 0.7 \mathrm{~m}, 1.3 \mathrm{~m}$ and thereafter in $2 \mathrm{~m}$ intervals, up to the $3 \mathrm{~cm}$ dbh limit.

Each sample tree was felled and the stem up to commercial height was divided into five sections of equal length. Stem discs (outside bark) approximately $2.5 \mathrm{~cm}$ thick were cut at both ends of the sections. An additional disc was cut at breast height (1.3m). The basic density of wood and bark, and the carbon content of wood in each one of these stem discs was assessed in the laboratory.

All the leaves of each sample tree were collected manually and the fresh weight was recorded. A sample of the fresh leaves was taken to the laboratory to determine dryweight/freshweight ratio $(D w / F w)$. The leaf samples were dried at $70 \pm 2{ }^{\circ} \mathrm{C}$ until the dry weight stabilized.

Similarly, the dry and green branches were removed and weighed separately. The stem tip was classified as a branch when its diameter was smaller than $3 \mathrm{~cm}$. Samples of dry and green branches of known weight were collected to determine $D w / F w$ in the laboratory. They were dried at $103 \pm 2{ }^{\circ} \mathrm{C}$ until the dry weight stabilized.

Nine sample trees belonging to three different diameter classes were selected for the root assessments. The root material was assessed in three different layers $(0 \mathrm{~cm}-20 \mathrm{~cm}, 20 \mathrm{~cm}-40 \mathrm{~cm}$ and $40 \mathrm{~cm}-80 \mathrm{~cm})$. The specific area assigned to each root-sample tree is based on the systematic $3 \mathrm{~m}$ spacing between planting rows and the depth of each layer. Thus, for the first two layers this volume would be $1.8 \mathrm{~m}^{3}(3 \cdot 3 \cdot 0.2)$ and for the third layer $3.6 \mathrm{~m}^{3}(3 \cdot 3 \cdot 0.4)$. Therefore, it was assumed that all the roots of the sample trees were located within a $3 \mathrm{~m}$ radius extending from the tree position (Figure 1).

This "root occupation area" (ROA) was divided into four quadrants. In one of these quadrants, 7 vertical cores, each measuring $40 \times 40 \mathrm{~cm}$ with a depth of 80 $\mathrm{cm}$ (divided in three layers), were used to excavate all the root material, including one-quarter of the tap root, within the ROA of each of the nine root-sample trees. This depth limit $(80 \mathrm{~cm})$ was chosen because most of the tree roots are usually located in the top $60 \mathrm{~cm}$ of the soil (HARMAND et al., 2004; SÁNCHEZ-PÉREZ et al., 2008). For each layer it was calculated the volume of each vertical core: for the first two layers $(0 \mathrm{~cm}-$ $20 \mathrm{~cm}$ and $20 \mathrm{~cm}-40 \mathrm{~cm})$, the volume is the same $(0.032$ $\left.\mathrm{m}^{3}\right)$, as they have the same depth $(20 \mathrm{~cm})$. For the 40 $\mathrm{cm}-80 \mathrm{~cm}$ layer the volume was $0.064 \mathrm{~m}^{3}$. A total surface area of $1.12 \mathrm{~m}^{2}\left(7 \cdot 0.16 \mathrm{~m}^{2}\right)$, or about one-half of the quadrant surface of $2.25 \mathrm{~m}^{2}(9 / 4)$ was sampled. All the material was weighed in the field. A root sample was oven-dried at $103 \pm 2{ }^{\circ} \mathrm{C}$ to determine $\mathrm{Dw} / \mathrm{Fw}$ in the laboratory.

The dry weight of the roots in each layer was scaled up to the ROA by considering the specific area assigned to each root sample and the sum of the volume of the seven vertical cores. For example, for the first layer $(0 \mathrm{~cm}-20 \mathrm{~cm})$, the dry weight of the roots was calculated as follows: [1.8.weight/(7·0.032)]. The weight of the taproot was estimated by multiplying its sampled weight

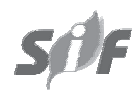

Revista Árvore, Viçosa-MG, v.39, n.2, p.353-363, 2015 
Table 1 - Identification of the 23 sample trees.

Tabela 1 - Identificação das 23 árvores-amostra.

\begin{tabular}{|c|c|c|c|c|c|c|}
\hline Tree $\mathrm{N}^{\mathrm{o}}$ & $\mathrm{dbh}(\mathrm{cm})$ & Total height (m) & $\begin{array}{l}\text { Commercial } \\
\text { height }(\mathrm{m})\end{array}$ & $\begin{array}{l}\text { Volume inside } \\
\text { bark }\left(\mathrm{m}^{3}\right)\end{array}$ & $\begin{array}{l}\text { Volume outside } \\
\text { bark }\left(\mathrm{m}^{3}\right)\end{array}$ & $\begin{array}{c}\text { Root sample } \\
\text { tree }\end{array}$ \\
\hline 1 & 10.0 & 18.0 & 15.1 & 0.061 & 0.052 & \\
\hline 2 & 11.2 & 20.2 & 17.5 & 0.095 & 0.079 & \\
\hline 3 & 11.8 & 21.7 & 19.2 & 0.109 & 0.096 & \\
\hline 4 & 12.1 & 23.2 & 20.9 & 0.135 & 0.118 & \\
\hline 5 & 12.3 & 23.1 & 21.0 & 0.137 & 0.117 & \\
\hline 6 & 12.8 & 22.9 & 20.6 & 0.141 & 0.125 & $\mathrm{X}$ \\
\hline 7 & 13.0 & 23.6 & 20.8 & 0.140 & 0.125 & $\mathrm{X}$ \\
\hline 8 & 13.3 & 24.0 & 22.0 & 0.164 & 0.140 & \\
\hline 9 & 13.4 & 23.7 & 21.6 & 0.161 & 0.141 & $\mathrm{X}$ \\
\hline 10 & 13.7 & 24.2 & 22.2 & 0.178 & 0.151 & \\
\hline 11 & 15.0 & 25.7 & 23.8 & 0.218 & 0.188 & $X$ \\
\hline 12 & 15.3 & 24.9 & 23.4 & 0.241 & 0.218 & $\mathrm{X}$ \\
\hline 13 & 15.3 & 25.3 & 23.5 & 0.232 & 0.206 & $\mathrm{X}$ \\
\hline 14 & 16.5 & 25.8 & 24.0 & 0.245 & 0.215 & \\
\hline 15 & 17.2 & 26.7 & 24.8 & 0.286 & 0.249 & \\
\hline 16 & 17.2 & 27.1 & 25.2 & 0.306 & 0.271 & \\
\hline 17 & 17.3 & 26.9 & 25.1 & 0.299 & 0.265 & \\
\hline 18 & 17.4 & 27.0 & 25.3 & 0.297 & 0.258 & \\
\hline 19 & 17.8 & 26.6 & 14.2 & 0.296 & 0.257 & $X$ \\
\hline 20 & 17.8 & 26.5 & 24.9 & 0.334 & 0.297 & $\mathrm{X}$ \\
\hline 21 & 18.3 & 27.0 & 25.2 & 0.309 & 0.265 & $X$ \\
\hline 22 & 18.5 & 27.1 & 25.3 & 0.326 & 0.287 & \\
\hline 23 & 18.7 & 27.3 & 25.6 & 0.347 & 0.301 & \\
\hline
\end{tabular}

by the factor 4 . The sum of the dry weights obtained in each layer, with the estimated weight of the taproot, gave the total dry weight of the roots of one sample tree.

The root/shoot ratio $(\mathrm{R} / \mathrm{S})$ was calculated for each one of the nine trees, considering the aboveground biomass as the sum of the biomass of stem, bark, branches and leaves.

\subsection{Biomass and carbon content of the 23 sample trees}

The biomass ratios $\left(\mathrm{Br}_{i}\right)$ of the branches, leaves and roots of sample trees were calculated as follows:

$$
B r_{i}=\frac{D w_{i}}{F w_{i}}
$$

where $D w_{i}$ and $F w_{i}$ refer to the sampled dry and fresh weights $(\mathrm{kg})$ of the $\mathrm{i}^{\text {th }}$ compartment respectively. These ratios were multiplied with the total fresh weights $(\mathrm{kg})$ of the whole compartment per tree obtained in the field $\left(F_{i}\right)$, to give the biomass in the field $\left(B_{i}\right)$ :

$$
B_{i}=F_{i} \cdot B r_{i}
$$

The total biomass of the stem and bark $\left(B_{i}\right)$ was calculated by multiplying the stem and bark volume with the average basic density of the wood ( $B D W)$ and bark $(B D B)$ :

$$
B_{i}=V_{i} \cdot(B D W o r B D B)
$$

where $V_{i}$ refers to volume of wood or bark $\left(\mathrm{m}^{3}\right)$, and $B D W$ and $B D B$ are the basic density of wood or bark $\left(\mathrm{kg} \mathrm{m}^{-3}\right)$, respectively.

The above- and belowground biomass of each sampled component was converted to carbon using the carbon content, which was obtained in the laboratory using a continuous-flow isotope ratio mass spectrometer (ANCA-GLS).

\subsection{Data analysis}

Allometric equations were adjusted to estimate the total amount of carbon (stem+bark+branches+leaves) of the 23 sample trees. As the carbon content of the bark was not available due to technical issues, it was calculated an average carbon content for the bark using the data of the other compartments (stem, branches and leaves).

Revista Árvore, Viçosa-MG, v.39, n.2, p.353-363, 2015 


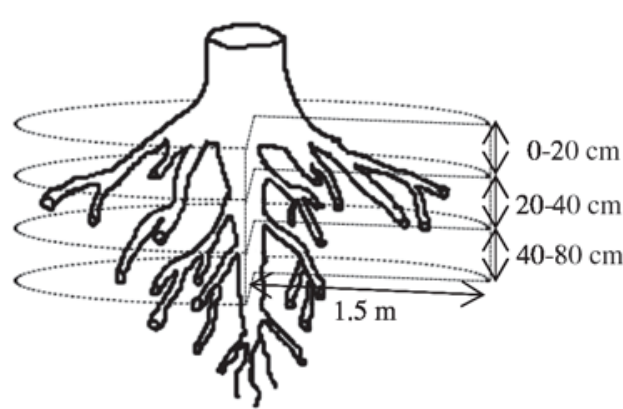

Root sampling: side view

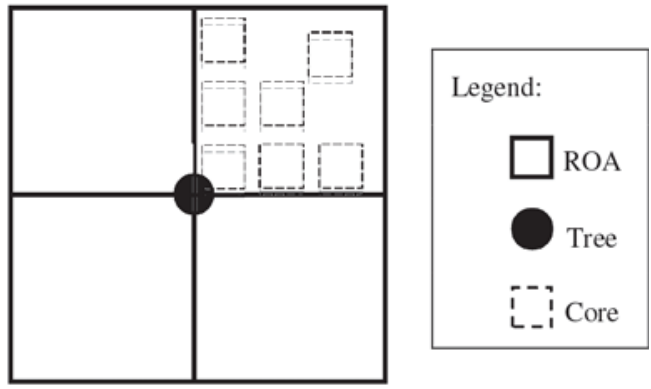

Root sampling: top view and legend

Figure 1 - Schematic representation of root sampling.

Figura 1 - Representação esquemática da amostragem das raízes.

As in many situations the carbon content of the biomass is not available, it was also decided to adjust an equation to estimate the aboveground tree biomass using the previous equations. The aboveground tree biomass (stem+branches+bark+leaves) and the $d b h$ and $H$ of the 23 sample trees were used in the model adjustment. The following models were fitted to the field data (SOARES et al., 2006):

$$
\begin{gathered}
Y_{1}=\beta_{01} \cdot d b h^{\beta_{11} \cdot H^{\beta_{21}} \cdot \varepsilon} \\
Y_{2}=\beta_{02} \cdot\left(d b h^{2} \cdot H\right)^{\beta_{12}} \cdot \varepsilon
\end{gathered}
$$

where $Y_{j}$ refers to the total amount of carbon or biomass $(\mathrm{kg})$ of the $\mathrm{j}^{\mathrm{th}}$ model; $H$ refers to the height $(\mathrm{m}) ; \beta_{0}, \beta_{1}$ and $\beta_{2}$ refer to parameters of the $\mathrm{j}^{\text {th }}$ model and $\varepsilon$ refers to random error.

A non-linear ordinary least squares-regression analysis was used to fit the models to the data. The significance of the models and the model coefficients were evaluated using the $F$-test and the $t$ statistic respectively. All the analyses were conducted using the STATISTICA software package version 8.0.

To select the best model the following evaluation criteria were used: a) logic of the sign (+/-) associated with a specific parameter; b) distribution of residuals; c) bias $(\bar{E})$, which tests the systematic deviation of the model from the observations; d) root mean square error (RMSE), which analyses the accuracy of the estimates; e) model efficiency ( $M E F$ ), which shows the proportion of the total variance that is explained by the model, adjusted for the number of model parameters and the number of observations. These criteria were calculated as follows (ÁLVAREZGONZÁLEZ et al., 2010):

$$
\begin{array}{r}
\bar{E}=\frac{\sum_{i=1}^{n}\left(y_{i}-\hat{y}_{i}\right)}{n} \\
R M S E= \pm \sqrt{\frac{\sum_{i=1}^{n}\left(y_{i}-\hat{y}_{i}\right)^{2}}{n-p}} \\
M E F=1-\frac{(n-1) \sum_{i=1}^{n}\left(y_{i}-\hat{y}_{i}\right)^{2}}{(n-p) \sum_{i=1}^{n}\left(y_{i}-\bar{y}_{i}\right)^{2}}
\end{array}
$$

where $y_{i}, \hat{y}_{i}$ and $\bar{y}_{i}$ are the observed, predicted and mean values of the dependent variable, respectively; $n$ is the total number of observations used to fit the function; and $p$ is the number of model parameters.

\subsection{Carbon stock estimates in the stand level}

The best fitted allometric equation derived from the 23 sample trees to estimate the total amount of carbon was used to predict the aboveground tree carbon stock on the stand level. The raw data was divided into four diameter size classes and the tree density and the average height $(\overline{\mathrm{H}})$ of each size class was calculated.

The diameter center class and the average height of each size class were used as independent variables in the allometric equation derived from the 23 sample trees. The amount of carbon obtained per size class was multiplied by the tree density in order to obtain 
an estimate of the stand's aboveground tree carbon stock.

The carbon stock of the roots was estimated based on the field estimates of carbon content and biomass. However, for the roots the raw data was divided into three diameter size classes. The diameter center class and the tree density of each size were calculated. The average amount of carbon obtained for each size class was multiplied by the tree density to estimate the belowground tree carbon stock on the stand level.

\section{RESULTS}

This section presents the above- and belowground biomass and carbon content of the 23 sample trees, the fitted allometric equations and the estimates of carbon stock in the stand level for a Eucalyptus plantation.

\subsection{Biomass and carbon content of the 23 sample trees}

The aboveground biomass and the carbon content in different compartments of the 23 sample trees are given in Table 2.

The stem is the compartment that contributed highly to the aboveground tree biomass $(82 \%)$, followed by the bark $(8 \%)$, branches $(7 \%)$ and leaves $(3 \%)$. Nonetheless, the carbon content follows a different pattern. The leaves have higher average carbon content (46.10\%), followed by the stem (44.61\%) and branches $(42.89 \%)$.

\subsection{Allometric equations}

The allometric models were fitted to the data using $d b h, H$ and the combined variable $d b h^{2} H$ as explanatory variables. The parameter estimates of each allometric equation tested, as well as the standard error for each parameter $(S E)$, bias $(\bar{E})$, root mean square error (RMSE) and model efficiency (MEF), are given in Table 3.

The equations to estimate the total carbon amount and total aboveground tree biomass generally fit the data well. The $M E F$ ranged from 0.9770 to 0.9798 . The $R M S E$ varied between 2.9492 and 6.8405 and $\bar{E}$ between -0.0545 and -0.0095 .

From the set of regression equations for predicting the total amount of carbon, equation $\mathrm{m}_{2}$ was chosen. Although is slightly higher than equation $\mathrm{m}_{1}$, in equation $\mathrm{m}_{2}$ all the variables were significant $(\alpha=0.05)$ and $M E F$ and RMSE were the highest and lowest, respectively. Similarly, equation $\mathrm{m}_{2}$ was the best equation to predict the total aboveground tree biomass. The equation fit the data well $(M E F=0.9781 ; R M S E=6.6816)$, albeit $\bar{E}$ is higher (-0.0545) than equation $\mathrm{m}_{1}$.

Scatter plots of the residuals revealed the absence of any apparent pattern and showed no trends of increasing variance (heteroscedasticity).

\subsection{Belowground biomass and carbon content of the nine sample trees selected for the root assessment}

The carbon content and root/shoot ratio (R/S) of the nine sub-sample trees are given in Table 4 .

Average R/S and carbon content for all root material of the nine sub-sample trees was 0.17 and $37.84 \%$, respectively. The biomass of roots ranged from 6.95 $\mathrm{kg}$ to $28.11 \mathrm{~kg}$, with a mean of $19.22 \mathrm{~kg}$.

\subsection{Above- and belowground carbon stock in the stand level}

The estimated carbon stock of the Eucalyptus plantation was obtained considering the carbon stored in the aboveground (stem, bark, branches and leaves) and belowground (roots) parts of the trees. The total carbon stock in the aboveground tree biomass of the Eucalyptus plantation was $63.7 \mathrm{MgC} \mathrm{ha}^{-1}$. Considering the contribution of each tree compartment in the aboveground biomass, the carbon stock for the stem, bark, branches and leaves accounted for 52.12, 5.09, 4.45 and $1.91 \mathrm{MgC} \mathrm{ha}^{-1}$, respectively.

The belowground carbon stock on the stand level is $9.81 \mathrm{MgC} \mathrm{ha}^{-1}$. Total stand carbon stock in the Eucalyptus plantation was estimated to be $73.38 \mathrm{MgC}$ $\mathrm{ha}^{-1}$. From this total, the above- and the belowground carbon stock represented $87 \%$ and $13 \%$, respectively.

\section{DISCUSSION}

The first part of this study focused on the assessment of aboveground tree biomass and carbon content of Eucalyptus urograndis clones in order to support the development of allometric equations to estimate the total amount of carbon and total aboveground biomass. The average carbon content determined in our study (Table 2) for the stem, branch, and leaf compartments was $44.6 \%, 43.0 \%$ and $46.1 \%$, respectively. 
Table 2 - Aboveground biomass ( $\mathrm{kg})$ and carbon content (\%) of sample trees.

Tabela 2 - Biomassa acima do solo $(\mathrm{kg})$ e teor de carbono (\%) das árvores-amostra.

\begin{tabular}{|c|c|c|c|c|c|c|c|c|c|c|}
\hline \multirow{2}{*}{ Tree $\mathrm{N}^{\mathrm{o}}$} & \multirow{2}{*}{$\operatorname{BDW}\left(\mathrm{kg} \mathrm{m}^{-3}\right)$} & \multirow{2}{*}{$\mathrm{BDB}\left(\mathrm{kg} \mathrm{m}^{-3}\right)$} & \multicolumn{5}{|c|}{ Biomass (kg) } & \multicolumn{3}{|c|}{ Carbon content (\%) } \\
\hline & & & Stem & Bark & Branches & Leaves & Total & Stem & Branches & Leaves \\
\hline 1 & 513 & 346 & 26.8 & 3.2 & 4.3 & 0.8 & 35.1 & 45.00 & 41.50 & 45.40 \\
\hline 2 & 525 & 346 & 41.7 & 5.4 & 5.9 & 1.2 & 54.2 & 44.30 & 42.25 & 44.70 \\
\hline 3 & 437 & 295 & 42.0 & 4.0 & 4.4 & 1.0 & 51.4 & 43.60 & 42.92 & 46.03 \\
\hline 4 & 450 & 317 & 53.1 & 5.4 & 4.1 & 1.5 & 64.1 & 44.50 & 41.10 & 46.90 \\
\hline 5 & 480 & 339 & 56.1 & 6.9 & 3.1 & 1.7 & 67.8 & 44.43 & 43.15 & 45.30 \\
\hline 6 & 455 & 347 & 56.9 & 5.6 & 4.1 & 1.5 & 68.1 & 44.80 & 42.75 & 39.10 \\
\hline 7 & 465 & 326 & 57.9 & 5.0 & 3.7 & 1.5 & 68.1 & 44.40 & 42.35 & 46.50 \\
\hline 8 & 474 & 328 & 66.5 & 7.7 & 3.8 & 2.2 & 80.2 & 45.20 & 41.35 & 47.55 \\
\hline 9 & 466 & 353 & 65.7 & 7.1 & 6.6 & 1.4 & 80.8 & 43.60 & 43.90 & 44.80 \\
\hline 10 & 474 & 344 & 71.5 & 9.2 & 6.3 & 2.3 & 89.3 & 45.50 & 42.85 & 43.30 \\
\hline 11 & 468 & 335 & 88.1 & 10.0 & 7.5 & 3.5 & 109.1 & 44.90 & 43.50 & 48.30 \\
\hline 12 & 458 & 349 & 99.7 & 8.2 & 7.4 & 3.8 & 119.1 & 44.30 & 43.00 & 47.20 \\
\hline 13 & 476 & 347 & 97.8 & 9.0 & 8.7 & 3.3 & 118.8 & 44.30 & 44.50 & 47.60 \\
\hline 14 & 458 & 316 & 98.7 & 9.4 & 9.1 & 3.9 & 121.1 & 44.70 & 43.15 & 45.10 \\
\hline 15 & 480 & 355 & 119.4 & 13.3 & 8.2 & 5.3 & 146.2 & 44.10 & 44.20 & 44.60 \\
\hline 16 & 476 & 342 & 129.0 & 12.0 & 8.6 & 5.8 & 155.4 & 44.90 & 42.85 & 47.90 \\
\hline 17 & 480 & 360 & 127.1 & 12.4 & 8.5 & 4.9 & 152.9 & 44.50 & 42.55 & 47.00 \\
\hline 18 & 481 & 345 & 124.2 & 13.2 & 9.0 & 5.5 & 151.9 & 44.90 & 43.60 & 48.00 \\
\hline 19 & 477 & 343 & 122.5 & 13.6 & 9.0 & 6.0 & 151.1 & 45.10 & 41.25 & 46.40 \\
\hline 20 & 495 & 342 & 146.8 & 12.9 & 8.9 & 5.2 & 173.8 & 44.10 & 44.70 & 47.20 \\
\hline 21 & 485 & 341 & 128.6 & 15.0 & 8.5 & 5.4 & 157.5 & 44.80 & 43.75 & 46.80 \\
\hline 22 & 480 & 326 & 137.8 & 12.8 & 8.7 & 7.0 & 166.3 & 44.50 & 41.25 & 47.80 \\
\hline 23 & 489 & 343 & 147.5 & 15.5 & 8.6 & 7.1 & 178.7 & 45.50 & 44.15 & 46.90 \\
\hline Mean & 475.74 & 338.47 & 91.54 & 9.43 & 6.83 & 3.55 & 111.35 & 44.61 & 42.89 & 46.10 \\
\hline$\left( \pm \mathrm{C} \cdot \mathrm{V}^{a}{ }^{a}\right)$ & $(4.0 \%)$ & $(4.3 \%)$ & $(41.2 \%)$ & $(39.4 \%)$ & $(31.4 \%)$ & $(58.3 \%)$ & $(40.5 \%)$ & $(1.1 \%)$ & $(2.5 \%)$ & $(4.4 \%)$ \\
\hline $\mathrm{SE} \%^{\mathrm{b}}$ & 0.84 & 0.90 & 8.58 & 8.21 & 6.54 & 12.16 & 8.45 & 0.24 & 0.53 & 0.91 \\
\hline $\mathrm{SM} \%{ }^{\mathrm{c}}$ & 1.73 & 1.88 & 17.81 & 17.02 & 13.57 & 25.21 & 17.53 & 0.49 & 1.09 & 1.89 \\
\hline $\mathrm{CI}^{\mathrm{d}}$ & $\begin{array}{l}476 \pm \\
8240\end{array}$ & $338 \pm$ & $\begin{array}{r}91.5 \pm \\
16298\end{array}$ & $\begin{array}{l}9.4 \pm \\
1605\end{array}$ & $6.8 \pm$ & $\begin{array}{l}3.6 \pm \\
0.896\end{array}$ & $\begin{array}{l}11.3 \pm \\
19.520\end{array}$ & $44.61 \pm$ & $\begin{array}{c}42.89 \pm \\
0.005\end{array}$ & $46.10 \pm$ \\
\hline
\end{tabular}

${ }^{\mathrm{a} C}$ C.V.: coefficient of variation. ${ }^{\mathrm{b}} \mathrm{SE} \%$ : relative standard error. ${ }^{\mathrm{C}} \mathrm{SM} \%$ : sampling error $(95 \% \mathrm{CI})$. ${ }^{\mathrm{d}} \mathrm{CI}$ : confidence interval $(95 \% \mathrm{CI})$.

Table 3 - Estimated regression coefficients and their standard errors $( \pm S E)$, model bias $(\bar{E})$, root mean square error $( \pm R M S E)$ and model efficiency (MEF) of the tested allometric models.

Tabela 3 - Coeficientes estimados de regressão e seus erros-padrão ( \pm SE), bias do modelo (E), erro médio quadrático ( \pm RMSE) e eficiência (MEF) das equações alométricas testadas.

\begin{tabular}{|c|c|c|c|c|c|c|}
\hline \multicolumn{7}{|c|}{ Total carbon amount } \\
\hline Model & Coefficient & Estimate & SE & $E$ & RMSE & MEF \\
\hline $\mathrm{m}_{1}$ & $\mathrm{~b}_{01}$ & 0.0067 & 0.0093 & -0.0095 & 3.0150 & 0.9789 \\
\hline & $b_{11}$ & 1.8605 & 0.3168 & & & \\
\hline & $b_{21}$ & 1.1865 & 0.6784 & & & \\
\hline $\mathrm{m}_{2}$ & $\mathrm{~b}_{02}^{21}$ & 0.0102 & 0.0034 & -0.0211 & 2.9492 & 0.9798 \\
\hline & $\mathrm{b}_{12}$ & 0.9776 & 0.0374 & & & \\
\hline \multicolumn{7}{|c|}{ Total aboveground tree biomass } \\
\hline Model & Coefficient & Estimate & $\mathrm{SE}$ & $\bar{E}$ & RMSE & MEF \\
\hline \multirow[t]{3}{*}{$\mathrm{m}_{1}$} & $\mathrm{~b}_{01}$ & 0.0192 & 0.0268 & -0.0385 & 6.8405 & 0.9770 \\
\hline & $\mathrm{b}_{11}$ & 1.8766 & 0.3191 & & & \\
\hline & $b_{21}$ & 1.0980 & 0.6814 & & & \\
\hline \multirow[t]{2}{*}{$\mathrm{m}_{2}$} & $\mathrm{~b}_{02}^{21}$ & 0.0249 & 0.0083 & -0.0545 & 6.6816 & 0.9781 \\
\hline & $\mathrm{b}_{12}$ & 0.9679 & 0.0377 & & & \\
\hline
\end{tabular}


Table 4 - Biomass ( $\mathrm{kg})$, carbon content (\%) and R/S of the nine sub-sample trees selected for the roots assessment. Tabela 4 - Biomassa (kg), teor de carbono (\%) e R/S de nove árvores-amostra selecionadas para avaliação das raízes.

\begin{tabular}{|c|c|c|c|}
\hline \multirow{2}{*}{ Tree $\mathrm{N}^{\mathrm{o}}$} & \multicolumn{2}{|c|}{ Roots } & \multirow{2}{*}{$\mathrm{R} / \mathrm{S}$} \\
\hline & Biomass (kg) & Carbon content $(\%)$ & \\
\hline 6 & 13.54 & 34.60 & 0.20 \\
\hline 7 & 6.95 & 37.10 & 0.10 \\
\hline 9 & 17.39 & 31.30 & 0.22 \\
\hline 11 & 27.33 & 44.70 & 0.25 \\
\hline 12 & 15.50 & 42.40 & 0.13 \\
\hline 13 & 18.71 & 40.60 & 0.16 \\
\hline 19 & 20.94 & 36.80 & 0.14 \\
\hline 20 & 28.11 & 35.30 & 0.16 \\
\hline 21 & 24.49 & 37.80 & 0.16 \\
\hline $\operatorname{Mean}\left(C . V^{a}\right)$ & $19.22(35.66 \%)$ & $37.84(10.93 \%)$ & $0.17(27.47 \%)$ \\
\hline $\mathrm{SE} \%{ }^{\mathrm{b}}$ & 11.89 & 3.64 & 9.16 \\
\hline $\mathrm{SM} \% \mathrm{c}$ & 27.41 & 8.40 & 21.11 \\
\hline $\mathrm{CI}^{\mathrm{d}}$ & $19.22 \pm 5.268$ & $37.84 \pm 0.032$ & $0.17 \pm 0.035$ \\
\hline
\end{tabular}

${ }^{\mathrm{a}} \mathrm{C} . \mathrm{V}$.: coefficient of variation. ${ }^{\mathrm{b}} \mathrm{SE} \%$ : relative standard error. ${ }^{\mathrm{d}} \mathrm{SM} \%$ : sampling error $(95 \% \mathrm{CI})$. ${ }^{\mathrm{c}} \mathrm{CI}$ : confidence interval (95\% CI).

A study with different native species of Eucalyptus in eastern Australian reported an average carbon content for leaves, branches and wood of $52.9 \%, 46.8 \%$ and $49.8 \%$ respectively (GIFFORD, 2000a). IPCC (2006) recommends that in the absence of specific carbon content values, a default carbon content of $47 \%$ should be used to estimate the carbon fraction in the aboveground forest biomass.

These carbon content values are high compared to the ones founded in this work, probably due to differences of species/clone, site and other environmental conditions. However, further comparisons are hampered by the scarce number of studies that quantified the carbon content in a laboratory. Most of the studies that aim to estimate the carbon stock in plantations (MIEHLE et al., 2006; RAZAKAMANARIVO et al., 2011; ZHANG et al., 2012) use a generic value of 50\% to estimate the carbon content in biomass.

The indiscriminate use of this value may have serious implications, especially under the Kyoto Protocol. Lamlom and Savidge (2003) argue that the use of $50 \%$ as a generic value for carbon content in biomass is an oversimplification, as it may lead to an under- or overestimation of carbon credit allocation in projects that are based on the use of forest resources.

The carbon content distribution among different compartments in the present results (leaves $>$ stem $>$ branches) resembles the ones obtained by Gifford (2000a), for different species of Eucalyptus in Australia, and Schumacher and Witschoreck (2004) for Eucalyptus sp. in Brazil. Nonetheless, for the biomass proportions among different compartments, we noticed some divergence between our results ( stem $=82 \%$, bark $=8 \%$, branches $=7 \%$ and leaves $=3 \%$ ) and those from other studies. Paixão et al. (2006) in a 6-year old Eucalyptus grandis plantation in Brazil obtained biomass proportions similar to ours $($ stem $=81.8 \%$, bark $=8.1 \%$, branches $=7.7 \%$ and leaves $=2.6 \%$ ). However, Assis (1999), Ferreira (1984) and Ladeira (2001) reported different biomass proportions for Brazilian stands of Eucalyptus grandis and Eucalyptus urophylla (4 - 7 years): $70.4 \%$ for the stem, $11.8 \%$ for bark, $10.6 \%$ for branches and $7.2 \%$ for leaves. We believe the divergence in the proportion of biomass allocation between the former studies and ours is associated with different site characteristics, species, age and stand management practices.

The allometric equations were fitted to the data using the amount of carbon as a dependent variable. The use of this variable instead of biomass was an attempt to allow the estimation of the total amount of carbon based solely on easily measureable variables such as $d b h$ and $H$. Nevertheless, this was only possible because we determined the carbon content of almost all the samples in this study.

The combination of $d b h$ and $H\left(d b h^{2} H\right)$ was a better predictor for the total amount of carbon and total biomass, than the use of single variables. This is consistent with

Revista Árvore, Viçosa-MG, v.39, n.2, p.353-363, 2015 
previous studies in which the composite variable $d b h^{2} H$ is has been suggested as a good predictor for biomass (and thus carbon) equations (e.g. ZEWDIE et al., 2009).

The belowground biomass (roots) was also assessed and its carbon content estimated. The $\mathrm{R} / \mathrm{S}$ ratio was relatively stable $(\mathrm{C} . \mathrm{V} .=27.5 \%)$ probably because the sub-sample was composed of clones. Beside the absence of genetic variation, all the individuals of the sub-sample were the same age ( 5.5 years) and presented a low variability of $\mathrm{dbh}(\mathrm{C} . \mathrm{V} .=17.8 \%)$. However, it is worth mentioning that the $\mathrm{R} / \mathrm{S}$ estimated in this study is valid only for trees and sites with similar conditions, as the $\mathrm{R} / \mathrm{S}$ depends on many factors such as nutrient and water availability, spacing, age, species and climatic zone (BARTON; MONTAGU, 2006).

The carbon content of the roots (37.8\%) was smaller than other values found in the literature. Gifford (2000b), Stape et al. (2008) and IPCC (2003) reported values of carbon content ranging from $42 \%$ to $50 \%$. However, as in the case of aboveground biomass, there are few studies that quantified the carbon content of roots in Eucalyptus (or in other species), as the use of 50\% as a general value is very common. As already mentioned this is not recommended. The estimates of tree carbon stock in the stand level for the above- and belowground parts were 63.57 and $9.81 \mathrm{MgC} \mathrm{ha}^{-1}$, respectively. These values are within the carbon stock range for Eucalyptus plantations. For instance, in a stand of Eucalyptus sp. (4 and 6 years old) in Brazil, Schumacher and Witschoreck (2004) found an aboveground carbon stock of $16.25-72.02 \mathrm{MgC} \mathrm{ha}^{-1}$ and a belowground one of $2.3-8.9 \mathrm{MgC} \mathrm{ha}^{-1}$. In another study on a 6-year old Eucalyptus grandis plantation, Paixão et al. (2006) reported a carbon stock of $47.7 \mathrm{MgC} \mathrm{ha}^{-1}$ in the above ground tree section and $14.71 \mathrm{MgC} \mathrm{ha}^{-1}$ for the roots.

\section{CONCLUSIONS}

In this study it was estimated the carbon content of different tree compartments of Eucalyptus urograndis clones, developed an allometric equation to estimate the amount of carbon and presented an estimate of the carbon stock in the stand level. The carbon content was slightly smaller than other studies, probably due to differences related to the site and species/clones. However, further studies that include the determination of carbon content in the laboratory should be conducted to allow reliable comparisons.
The regression models to predict the total amount of carbon using the combination of $d b h$ and $H\left(d b h^{2} H\right)$ performed better than models based on single variables. The carbon stock in the stand level is within the range of other studies, despite the small sample size.

\section{ACKNOWLEDGEMENTS}

This research was funded by FAPEMIG (grant No. CAG2327-07), DAAD/CAPES (Ph.D. scholarship) and CNPq (productivity grants). The authors thank Plantar S.A. Reflorestamentos for providing the logistical support and staff during the field work. The authors are also indebted to M.Sc. Jarbas Silva Borges and M.Sc. Celso Coelho de Souza for assistance in field data collection and in laboratory work.

\section{REFERENCES}

ABRAF. Anuário estatístico da ABRAF 2012, ano base 2011. Brasília: Associação Brasileira de Produtores de Florestas Plantadas, 2012. 140p.

ÁLVAREZ-GONZÁLEZ, J.G.; ZINGG, A.; GADOW, K.V. Estimating growth in beech forests: a study based on long term experiments in Switzerland. Annals of Forest Science, v.67, p.1-13, 2010.

ASSIS, R.L.; FERREIRA, M.; MORAIS, E.J.; FERNANDES, L.A. Produção de biomassa de Eucalyptus urophylla S.T. Blake sob diferentes espaçamentos na região de cerrado de Minas Gerais. Revista Árvore, v.23, n.2, p.151-156, 1999.

BARTON, C.V.M.; MONTAGU, K.D. Effect of spacing and water availability on root:shoot ratio in Eucalyptus camaldulensis. Forest Ecology and Management, v.221, n.1, p.52-62, 2006.

FEHRMANN, L; KLEINN, C. General considerations about the use of allometric equations for biomass estimation on the example of Norway spruce in central Europe. Forest Ecology and Management, v.236, p.412421,2006

FERREIRA, M.G.M. An analysis of the productivity of Eucalyptus grandis plantations in the "Cerrado" region in Brasil: a nutrient cycling approach. 1984. 230f. Tese (Doutorado) - University of British Columbia, Vancouver, 1984.

Revista Árvore, Viçosa-MG, v.39, n.2, p.353-363, 2015 
GIFFORD, R.M. Carbon contents of aboveground tissues of forests and woodland trees. Melbourne: National Carbon Accounting System/Australian Greenhouse Office, CSIRO Plant Industry, 2000a. 27p.

GIFFORD, R.M. Carbon content of woody roots: revised analysis and a comparison with woody shoot components. Melbourne: National Carbon Accounting System/Australian Greenhouse Office, CSIRO Plant Industry, 2000b. 16p. (Technical Report, 7)

GONÇALVES, J.L.M.; STAPE, J.L.; LACLAU, J.P.; BOUILLET, J.P.; RANGER, J. Assessing the effects of early silvicultural management on longterm site productivity of fast-growing eucalypt plantations: The Brazilian experience. Southern Forests, v.70, p.105-118, 2008.

HARMAND, J.M.; NJITI, C.F.; BERNHARDREVERSAT, F.; PUIG, H. Aboveground and belowground biomass, productivity and nutrient accumulation in tree improved fallows in the dry tropics of Cameroon. Forest Ecology and Management, v.188, p.249-265, 2004.

HENRY, M.; BESNARD, A.; ASANTE, W.A.; ESHUN, J.; ADU-BREDU, S.; VALENTINI, R.; BERNOUX, M.; SAINT-ANDRÉ, L. Wood density, phytomass variations within and among trees, and allometric equations in a tropical rainforest of Africa. Forest Ecology and Management, v.260, p.1365-1388, 2010.

IGLESIAS, G.T.; WISTERMANN, D. Eucalyptus universalis. Global cultivated Eucalyptus forest map. Eucalyptologics: Information on Eucalyptus cultivation worlwide. 2009. GIT Forestry Consulting. Disponível em: $<$ http:// www.git-forestry.com>. Acesso em 12 abr. 2013.

IPCC. Good practice guidance for land use, land-use change and forestry. Prepared by Penman J.; Gytarsky M.; Hiraishi T.; Krug T., Kruger D.; Pipatti R.; Buendia L.; Miwa K.; Ngara T.; Tanabe K.; Wagner F. (Ed). Japan: IGES, 2003. 590p.

IPCC. 2006 IPCC Guidelines for National Greenhouse Gas Inventories. Prepared by the National Greenhouse Gas
Inventories Programme; Eggleston H.S.; Buendia L.; Miwa K.; Ngara T.; Tanabe K. (Ed.). Japan: IGES, 2006.

KAUFFMAN, J.B.; HUGHES, R.F.; HEIDER, C. Carbon pool and biomass dynamics associated with deforestation, land use, and agricultural abandonment in the neotropics. Ecological Applications, v. 19, p.1211-1222, 2009.

LACLAU, J.P.; RANGER, J.; GONÇALVES, J.L.M.; MAQUÈRE, V.; KRUSCHE, A.V.; M'BOU, A.T.; NOUVELLON, Y.; SAINT-ANDRÉ, L.; BOUILLET, J.P.; PICCOLO, M.C.; DELEPORTE, P.

Biogeochemical cycles of nutrients in tropical Eucalyptus plantations: Main features shown by intensive monitoring in Congo and Brazil. Forest Ecology and Management, v.259, p.17711785, 2010.

LADEIRA, B.C.; REIS, G.G.; REIS, M.G.F.; BARROS, N.F. Produção de biomassa de eucalipto sob três espaçamentos, em uma sequência de idade. Revista Árvore, v.25, n.1, p.69-78, 2001.

LAMLOM, S.H.; SAVIDGE, R.A. A reassessment of carbon content in wood: variation within and between 41 North American species. Biomass and Bioenergy, v.25, p.381-388, 2003.

MATONDO, R.S.; DELEPORTE, P.; LACLAU, J.P.; BOUILLET, J.P. Hybrid and clonal variability of nutrient content and nutrient use efficiency in Eucalyptus stands in Congo. Forest Ecology and Management, v.210, p.193-204, 2005.

MIEHLE, P.; LIVESLEY, S.J.; FEIKEMA, P.M.; LI, C.; ARNDT, S.K. Assessing productivity and carbon sequestration capacity of Eucalyptus globulus plantations using the process model Forest-DNDC: calibration and validation. Ecological

Modelling, v.192, n.1, p.83-94, 2006.

PAIXÃO, F.A.; SOARES, C.P.B.; JACOVINE, L.A.G.; SILVA, M.L.; LEITE, H.G.; SILVA, G.F. Quantificação do estoque de carbono e avaliação econômica de diferentes alternativas de manejo em um plantio de eucalipto. Revista Árvore, v.30, n.3, p.411-20, 2006.

PARRESOL, B.R. Assessing tree and stand biomass: a review with examples and critical comparisons. Forest Science, v.45, n.4, p.573593, 1999. 
RAZAKAMANARIVO, R.H.; GRINAND, C.; RAZAFINDRAKOTO, M.A.; BERNOUX, M.; ALBRECHT, A. Mapping organic carbon stocks in eucalyptus plantations of the central highlands of Madagascar: a multiple regression approach. Geoderma, v.162, n.3, p.335-346, 2011.

ROCKWOOD, D.L.; RUDIE, A.W.; RALPH, S.A.; ZHU, J.Y.; WINANDY, J.E. Energy product options for Eucalyptus species grown as short rotation woody crops. International Journal of Molecular Sciences, v.9, n.8, p.1361-1378, 2008.

SÁNCHEZ-PÉREZ, J.M.; LUCOT, E.; BARIAC, T.; TRÉMOLIÈRES, M. Water uptake by trees in a riparian hardwood forest (Rhine floodplain, France). Hydrological Processes, v. 22, p. 366-375, 2008.

SCHLAMADINGER, B.; BIRD, N.; JOHNS, T.; BROWN, S.; CANADELL, J.; CICCARESE, L.; DUTSCHKE, M.; FIEDLER, J.; FISCHLIN, A.; FEARNSIDE, P.; FORNER, C., FREIBAUER, A.; FRUMHOFF, P.; HOEHNE, N.; KIRSCHBAUM, M.U.F.; LABAT, A.; MARLAND, G.; MICHAELOWA, A.; MONTANARELLA, L.; MOUTINHO, P.; MURDIYARSO, D.; PENA, N.; PINGOUD, K.; RAKONCZAY, Z.;

RAMETSTEINER, E.; ROCK, J.; SANZ, M.J.; SCHMEIDER, U.A.; SHVIDENKO, A.; SKUTSCH, M.; SMITH, P.; SOMOGYI, Z.; TRINES, E.; WARD, M.; YAMAGATA, Y. A synopsis of land use, land-use change and forestry (LULUCF) under the Kyoto Protocol and Marrakech Accords. Environmental Science \& Policy, v.10, n.4, p.271-282, 2007.

SCHUMACHER, M.V.; WITSCHORECK, R. Inventário de carbono em povoamentos de Eucalyptus ssp. nas propriedades fumageiras do sul do Brasil: "um estudo de caso". In: SANQUETTA, C.R.; BALBINOT, R.; ZILLIOTTO, M.A. Fixação de carbono: atualidades, projetos e pesquisas. Curitiba: AM Impressos, 2004. p.111-24.

SILVÉRIO, F.O.; BARBOSA, L.C.A.; MALTHA, C.R.A.; SILVESTRE, A.J.D.; PILO-VELOSO, D.;
GOMIDE, J.L. Characterization of lipophilic wood extractives from clones of Eucalyptus urograndis cultivate in Brazil. Bio Resources, v. 2, p. 157$168,2007$.

SOARES, C.P.B.; PAULA NETO, F.; SOUZA, A.L. Dendrometria $\mathrm{e}$ inventário florestal. Viçosa, MG: Universidade Federal de Viçosa, 2006. 276p.

STAPE, J.L.; BINKLEY, D.; RYAN, M.G. Production and carbon allocation in a clonal Eucalyptus plantation with water and nutrient manipulations. Forest Ecology and Management, v.255, p.920-930, 2008.

STAPE, J.L.; GONÇALVES, J.L.M.; GONÇALVES, A.N. Relationships between nursery practices and field performance for Eucalyptus plantations in Brazil: a historical overview and its increasing importance. New Forests, v.22, n.1, p.19-41, 2001.

STERN, N. The economics of climate change: The stern review. Cambridge: Cambridge University Press, 2007. 712p.

WEI, R.P.; XU, D. Proceedings of the International Symposium Eucalyptus Plantations: research, management and development. Guangzhou: September 1-6, 2002. Singapore: World Scientific Publishing, 2002.

ZEWDIE, M.; OLSSON, M.; VERWIJST, T. Aboveground biomass production and allometric relations of Eucalyptus globulus Labill. coppice plantations along a chronosequence in the central highlands of Ethiopia. Biomass and

Bioenergy, v.33, p.421-428, 2009.

ZHANG, H.; GUAN, D.; SONG, M. Biomass and carbon storage of Eucalyptus and Acacia plantations in the Pearl River Delta, South China. Forest Ecology and Management, v.277, p.90-97, 2012.

ZHOU, X.D.; XIE, Y.J.; CHEN, S.F.; WINGFIELD, M.J. Diseases of eucalypt plantations in China: challenges and opportunities. Fungal Diversity, v.32, n.1, p.1-7, 2008. 